Meta

Journal des traducteurs

Translators' Journal

\title{
A Study on Translation Strategies of Culture-Specific Items
}

\section{Hyerim Kim et Jiyeon Kim}

Volume 60, numéro 2, août 2015

$60^{\mathrm{e}}$ anniversaire. Les horizons de la traduction : retour vers le futur

$60^{\text {th }}$ Anniversary. Translation's Horizons: Back to the Future

60mo aniversario. Los horizontes de la traducción: regreso al futuro

URI : https://id.erudit.org/iderudit/1032901ar

DOI : https://doi.org/10.7202/1032901ar

Aller au sommaire du numéro

Éditeur(s)

Les Presses de l’Université de Montréal

ISSN

0026-0452 (imprimé)

1492-1421 (numérique)

Découvrir la revue

Citer ce document

Kim, H. \& Kim, J. (2015). A Study on Translation Strategies of Culture-Specific Items. Meta, 60(2), 350-350. https://doi.org/10.7202/1032901ar d'utilisation que vous pouvez consulter en ligne.

https://apropos.erudit.org/fr/usagers/politique-dutilisation/ 


\title{
A Study on Translation Strategies of Culture-Specific Items
}

\author{
Hyerim Kim and JiYeon Kim \\ Ewha Womans University, Seoul, Korea \\ hyerim@ewha.ac.kr
}

The present study, based on findings from the review and analysis of current translation practices of culture-specific items, aims to identify factors that must be taken into account when translating culture-specific terms by language (English, Chinese, and Japanese) and propose translation strategies for such terms.

In order to achieve the objective of this study, outcomes of the Study on the Current State of Translation and Translation Strategies of Culture-Specific Items, a policy task of the National Institute of the Korean Language, has been introduced and used as the basis for review of major factors that need to be considered when translating cultural references. Communicability, accuracy, stability, and economy were found to be the main factors for consideration. Due to the unique characteristics of culture-specific items, phonetic information was also confirmed to be a major factor.

The current study proposes the following translation strategies. First, when translating into English, transliteration utilizing the system for Romanizing Korean is recommended, but in order to overcome the limitations of providing phonetic information alone, transliteration should be accompanied by semantic translation to deliver both phonetic and semantic information. Second, in the case of translation into Chinese, "sound-meaning combination translation" or transliteration supplemented by semantic translation in parentheses is proposed. For this, a Korean-to-Chinese transliteration chart and standardization of such combination translation practices are called for. Finally, when translating into Japanese, the recommended strategy is to transliterate the Korean term into katakana to deliver phonetic information and present graphological translation or explanatory translation in parentheses to secure communicativeness.

Hyerim Kim is a professor at Ewha Womans University GSTI, and a PhD in the Chinese language and literature (Hankuk University of Foreign Studies, 2003). She has wide experience in editing translations of various works from the Chinese cultural sphere, and is a veteran international conference interpreter with 25 years of experience. Currently, she is serving as chairman of the National Institute of the Korean Language's Public Terminology Standardization Committee, member of the Korea Tourism Organization's Advisory Committee for Spelling of Foreign Loan Words, and member of the National Language Deliberation Council under the Ministry of Culture, Sports and Tourism. Her major translations and publications include Hyerim Kim's Chinese Translation and Interpretation Dictionary (Ewha Womans University Press) and The History of Chinese Translation Ideology (Ewha Womans University Press). 